\title{
ANALISA KENYAMANAN TERMAL ADAPTIF PADA RUMAH TINGGAL TIPE 36 DI PERUMAHAN KETAPING RESIDENCE PADANG PARIAMAN
}

\author{
Richi Yulistia Riskillah ${ }^{1}$, Sisca Olivia ${ }^{2}$, Atthaillah ${ }^{3}$, Said Husain ${ }^{4}$, Eri Saputra ${ }^{5}$ \\ ${ }^{1}$ Program Studi Arsitektur, Universitas Malikussaleh, email: richiriskillah@gmail.com \\ ${ }^{2}$ Program Studi Arsitektur, Universitas Malikussaleh, email: sisca.olivia@unimal.ac.id \\ ${ }^{3}$ Program Studi Arsitektur, Universitas Malikussaleh, email: atthaillah@unimal.ac.id \\ ${ }^{4}$ Guntomara "Islamic Art and Architecture", email: guntomara.art@gmail.com \\ ${ }^{5}$ Program Studi Arsitektur, Universitas Malikussaleh, email: erisaputra@unimal.ac.id
}

\begin{abstract}
ABSTRAK
Rumah merupakan tempat terjadinya aktivitas manusia dalam sehari-hari, dalam melakukan aktivitas di dalam rumah diperlukan kenyamanan bagi pengguna. Kenyamanan termal merupakan salah satu hal yang harus diperhatikan. Penelitian ini dilakukan untuk memahami kondisi termal pada rumah tinggal sederhana dengan metrik adaptive comfort. Tujuan penelitian ini untuk mengetahui dan mendapatkan data tingkat kenyamanan termal. Rumah yang digunakan dalam penelitian ini yaitu Perumahan Kataping Residence, merupakan perumahan dengan jumlah unit bangun pada 1 tahap yaitu 145 unit dengan satu jenis bangunan yaitu tipe 36. Perumahan ini merupakan perumahan skala besar yang dibangun pada daerah Bandara Internasional Minangkabau (BIM) Padang Pariaman dengan desain menggunakan jendela adaptif. Dalam penggunaannya penghuni menggunakan penghawaan buatan untuk mendapatkan kondisi termal yang baik. Penelitian ini menggunakan metode simulasi dengan teknik parametrik menggunakan Rhinoceros, Grasshopper, Ladybug, dan Honeybee, serta menggunakan data cuaca Kota Padang Pariaman. Simulasi dilakukan 24 jam dalam sehari selama 1 (satu) tahun, dengan menggunakan 2 (dua) rumah contoh yang berbeda arah orientasinya. Hasil simulasi menunjukkan bahwa rumah dengan rata-rata tidak nyaman terjadi pada rumah contoh 2, dengan arah bagian barat merupakan orientasi paling tidak nyaman.
\end{abstract}

Kata kunci: perumahan, rumah, kenyamanan termal adaptif, kenyamanan termal, simulasi komputasi.

Info Artikel:

Dikirim: 9 Februari 2021; Revisi: 11 Februari 2021; Diterima: 21 Maret 2021; Diterbitkan: 31 Maret 2021

(C2021 The Author(s). Published by Arsitekno, Architecture Program, Universitas Malikussaleh, Aceh, Indonesia under the Creative Commons Attribution 4.0 International License (https://creativecommons.org/licenses/by/4.0/).

\section{PENDAHULUAN}

Perumahan Kataping Residence merupakan perumahan dengan jumlah unit bangun pada satu tahap yaitu 145 unit dengan bangunan hanya tipe 36 (Gambar $1 \& 2$ ). Perumahan ini merupakan perumahan skala besar yang dibangun pada daerah Bandara Internasional Minangkabau (BIM) Padang Pariaman. Perumahan Kataping Residence ini berada di Jalan Jalur 2 BIM Kabupaten Padang Pariaman. Desain rumah dibuat sama pada setiap unitnya, yang membedakan hanya arah orientasi peletakan rumah, yaitu menghadap sisi Timur dan sisi Barat.

Bentuk dan bukaan dibuat agar penghuni menggunakan penghawaan alami, dilihat dari ventilasi terbuka dan jendela yang bisa dibuka selebar $40 \%$. Bukaan pada rumah tersebut hanya terdapat pada bagian depan dan belakang. Kenyataannya rata-rata penghuni menggunakan penghawaan buatan berupa kipas angin atau air conditioning (AC) untuk mendapatkan kondisi termal yang baik.

Pengguna banyak menghabiskan waktunya dalam melakukan aktivitas di dalam rumah. Aktivitas tersebut berupa istirahat, memasak, bercengkrama ataupun sekedar menghabiskan waktu dengan keluarga. Hal ini menyebabkan manusia membutuhkan rumah sehat yang layak 
huni dan memiliki udara yang segar. Sebagian besar penghuni rumah menggunakan penghawaan buatan untuk menciptakan kenyamanan yang berdampak pada penggunaan energi terutama listrik. Pemborosan terjadi jika hal ini berlangsung secara menerus, jadi memaksimalkan penghawaan alami pada rumah memberikan temperatur termal yang baik.

Hipotesa yang didapatkan yaitu rumah tersebut tidak memiliki kenyamanan termal yang maksimal ditinjau dari penggunaan penghawaan buatan oleh penghuni. Penelitian kenyamanan termal pada rumah tinggal di Perumahan Ketaping Residence tipe 36 dilakukan untuk menganalisis kondisi termal. Penelitian ini menggunakan simulasi komputasi dengan perhitungan metrik adaptive comfort yang menyesuaikan dengan kondisi sebenarnya.

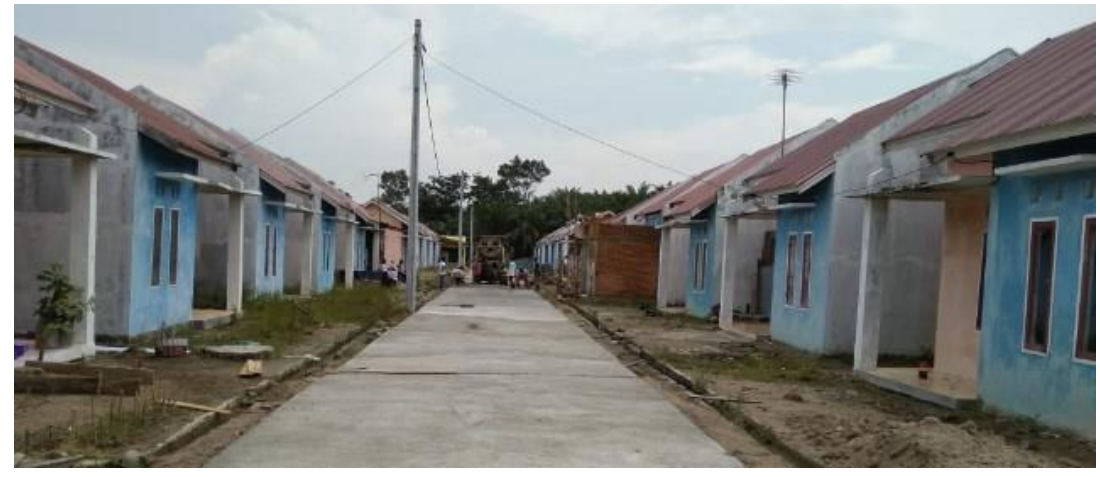

Gambar 1. Perumahan Ketaping Residence

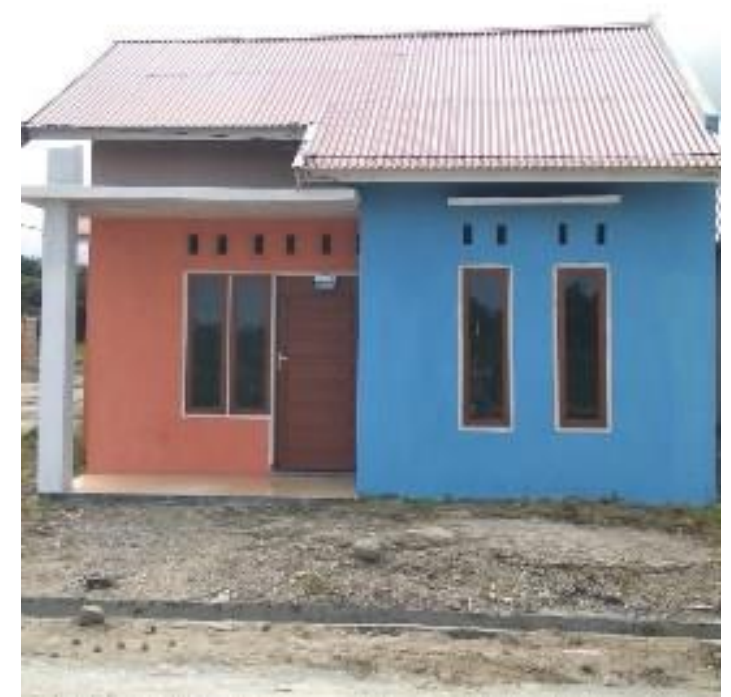

Gambar 2. Tampak rumah Ketaping Residence

Kenyamanan termal merupakan kondisi puas yang dirasakan seseorang terhadap lingkungannya [1]. Dapat dijabarkan bahwa kenyamanan adalah perasaan puas terhadap lingkungan baik psikologis maupun fisiologis [2]. Ketika seseorang merasakan nyaman dengan lingkungannya tanpa perubahan suhu, itu menandakan keadaan termal yang baik. Selanjutnya [3] menyatakan kenyamanan merupakan keadaan yang membuat pengguna merasa senang, yang tidak ada permintaan perubahan suhu. Sehingga kenyamanan termal terjadi di saat seseorang merasa tenang dan senang terhadap lingkungan baik secara psikologis maupun fisiologis. Standar Indonesia menetapkan bahwa kelembaban udara relatif untuk daerah tropis yaitu 40\%-50\%, dan pada ruangan yang padat 55\%-60\%. Daerah tropis memiliki 3 klasifikasi kenyamanan termal yaitu; suhu sejuk-nyaman $20,5^{\circ} \mathrm{C}-22,8^{\circ} \mathrm{C}$, suhu nyaman-optimal $22,8^{\circ} \mathrm{C}-25,8^{\circ} \mathrm{C}$, suhu mendekati nyaman $25,8^{\circ} \mathrm{C}-27,1^{\circ} \mathrm{C}[4]$. 


\section{Kenyamanan Termal Adaptif}

Kenyamanan adaptif yaitu kemampuan menyesuaikan suhu dengan kondisi lingkungannya. Menurut [5] perkembangan kenyamanan termal adaptif disebabkan karena faktor yang menggunakan keadaan lingkungan luar untuk mendapatkan kenyamanan termal. Kondisi luar yang memiliki temperatur yang sesuai dapat menciptakan kenyamanan termal yang baik. Bukaan yang dibuat optimal dapat membantu untuk memasukkan udara ke dalam bangunan. Menurut [6] peengoptimalan desain jendela adaptif dapat menurunkan kelembaban 1,92\% pada musim kemarau. Untuk mendapatkan kenyamanan termal adaptif yang baik perlu memperhatikan keadaan lingkungan di sekitarnya.

Perkembangan kenyamanan adaptif mulai diperhatikan dengan adanya penetapan standar ASHRAE 55 pada tahun 2004. Sebelum adanya kenyamanan adaptif, terlebih dahulu menggunakan kenyamanan Predicted Mean Vote (PMV) yang dikemukakan oleh Fanger pada tahun 1972, beda antara PMV dan adaptive comfort yaitu pada penggunaan atau tidak digunakan penghawaan buatan [7]. Kenyamanan adaptif lebih memperhatikan kondisi termal pada bangunan tanpa menggunakan penghawaan buatan. Hal ini dapat direalisasikan dengan memperhatikan bukaan pada bangunan tertentu. Bukaan menjadi salah satu faktor yang mempengaruhi kenyamanan termal.

Richard de Dear melakukan penyempurnaan terbaru mengenai standar kenyamanan termal ASHRAE 55 [8]. Menurut [5] kondisi luar berpengaruh terhadap keadaan suhu di dalam bangunan. Hal ini terjadi karena panas matahari tidak langsung masuk ke dalam ruangan melainkan disaring terlebih dahulu oleh konteks di sekitar bangunan dan material bangunan.

\section{METODE PENELITIAN}

Penelitian ini merupakan penelitian simulasi yang dilakukan dengan memodelkan ulang suatu objek ke dalam bentuk tiruan yang sesuai dengan aslinya. Simulasi digital merupakan kegiatan meniru sesuatu dengan bantuan perangkat lunak [9]. Hal ini sangat mempermudah dalam mengolah data dengan kecepatan dan keakuratan hasil yang diberikan. Penggunaannya sangat membantu dalam melakukan input data sesuai kondisi di lapangan ke dalam bentuk tiruan yang mewakilkan material, cuaca, suhu, tekstur dan luas permukaannya. Penelitian ini menggunakan piranti lunak Rhinoceros 5 SR8 (64-bit) (RH) dan Grasshopper 0.9.0076 (GH) dengan bantuan plug-in Ladybug (LB) versi 0.0.66 dan Honeybee (HB) 0.0.63 serta EnergyPlus (E+) 8.6.0.

LB digunakan agar bisa terhubung dengan E+, Radiance, Daysim, dan Open Studio [10]. Simulasi adaptive comfort dilakukan dengan bantuan E+ dan melakukan input data cuaca Kota Padang dalam format EnergyPlus Weather (.EPW). Penggunaan file EPW bertujuan untuk mendapatkan kondisi cuaca yang sebenarnya di Kota Padang. Hal ini untuk mempermudah dalam simulasi kenyamanan termal yang dirasakan, hasil yang didapatkan lalu divisualkan ke dalam bentuk grafis.

Data kondisi cuaca untuk lokasi penelitian menggunakan data EnergyPlus Weather (.EPW) Ketabing, Padang, Sumater Barat, Indonesia. Data cuaca ini akan menjadi data analisa dalam hasil simulasi. Dari data diagram matahari terlihat bahwa orientasi dari arah Timur ke Barat, dimana berarti arah matahari yang didapatkan dalam posisi miring. Hal ini juga memberikan efek radiasi dari arah yang sama (Gambar 3). Untuk data kecepatan dan arah angin rata-rata dalam setahun (Gambar4), arah angin datang dari Barat dan Utara dengan kecepatan antara 2,31- 4,62 m/s.

Hal pertama yang dilakukan yaitu memodelkan bangunan di RH lalu dihubungkan ke GH dengan bantuan Brep. Selanjutnya Brep tersebut di-input ke dalam Honeybee_Masses2Zone untuk diubah menjadi zona-zona sehingga masa bangunan dapat dibaca dan disimulasikan dengan komponen HB. Zona tersebut dihubungkan ke Solve_Adjacencies untuk dibagi berdasarkan komponen pada rumah seperti, atap, dinding, lantai dan lainnya. Sedangkan untuk mendapatkan bukaan diperlukan Honeybee_AddHbGlz yang nantinya juga memberikan akses untuk menambahkan properti material pada bangunan. Properti material bangunan memiliki data karakterisitik yang juga di-input dalam simulasi kenyamanan termal pada tabel 1 .

Selanjutnya pemberian zone load karena input yang diberikan berpengaruh terhadap simulasi kenyamanan termal tersebut. Zone load disesuaikan dengan keadaan rumah tersebut, mulai dari equipment load per area yang merupakan perhitungan pada area kerja yang menggunakan laptop, di sini diberikan nilai 2 sesuai dengan ketetapan untuk penggunaan 1 (satu) atau 2 (dua) laptop. 
Beban infiltrasi yang ada disesuaikan dengan keadaan bangunan dengan nilai $0,0003 \mathrm{~m}^{3} / \mathrm{s}$ per $\mathrm{m}^{2}$ facade, sedangkan pada beban pengguna diberikan nilai sebanyak 0,08 berdasarkan perhitungan 4 orang pengguna per jumlah luas ruangan. Pada franction of glazing operable diberikan input sebanyak 40 persen area bukaan yang dapat dioperasikan. Hal ini dapat dirangkum seperti pada tabel 2.
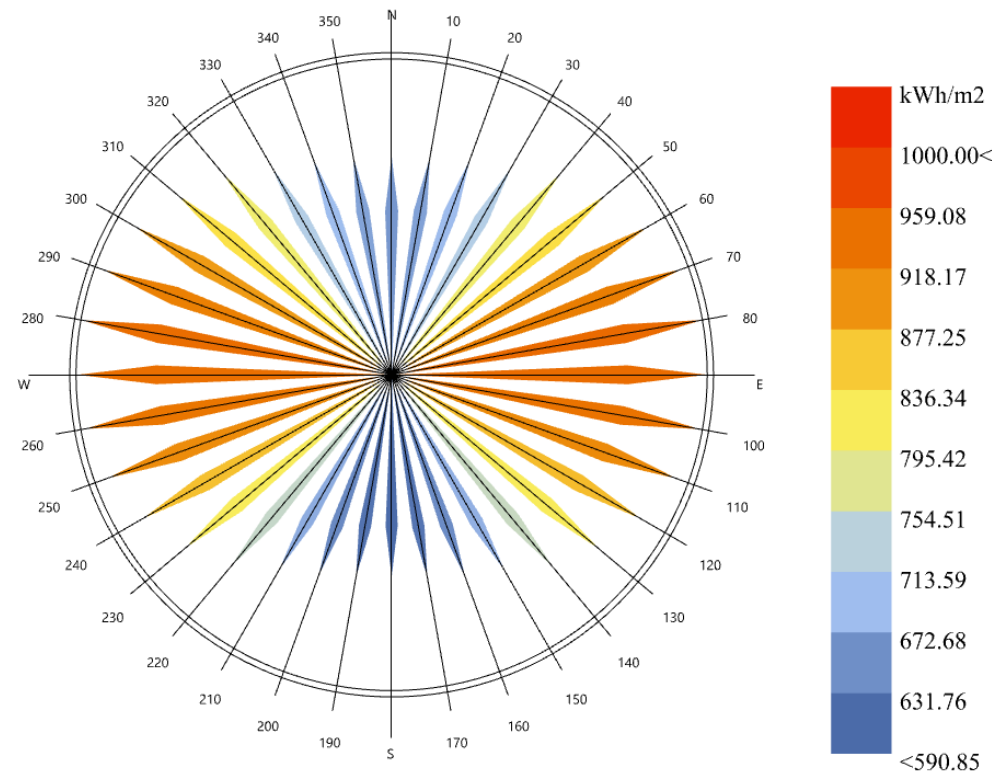

Gambar 3. Data radiasi Kota Padang

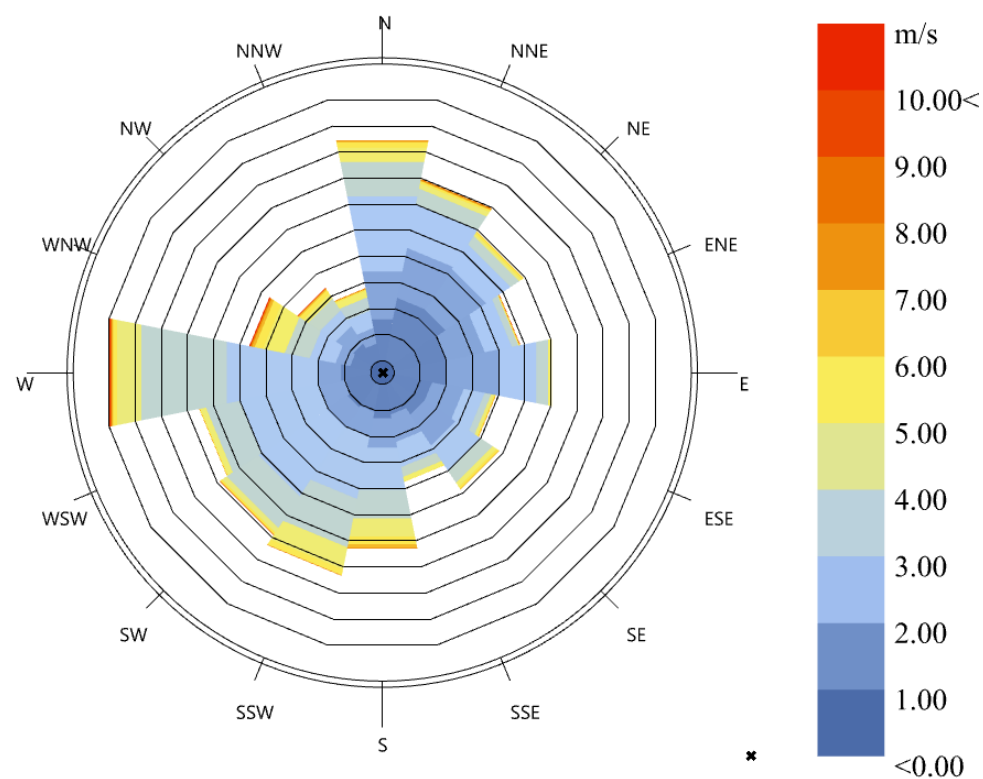

Gambar 4. Kecepatan dan arah angin Kota Padang

Langkah berikutnya untuk melakukan simulasi diperlukan konteks yang terdapat di sekitar bangunan dengan bantuan Honeybee_Ep Context Surface, pada rumah ini berupa overhang, dinding luar yang tidak memiliki ruang dan bangunan di sekitarnya, yang menyesuaikan dengan ukuran sebenarnya.

Setelah zona dan konteks didapatkan selanjutkan di-input ke dalam E+ untuk dilakukan simulasi. Untuk mendapatkan hasil yang sesuai maka data cuaca yang digunakan yaitu data cuaca untuk lokasi seperti telah dijelaskan sebelumnya. Selain itu komponen penting yang diperlukan yaitu Ladybug_Analysis Period untuk lama waktu yang dianalisis. Sedangkan untuk mendapatkan temperatur dan matrik kenyamanan maka pada Honeybee_Ep Output bagian yang dijalankan 
yaitu ZoneComfortMatrix dan SurfaceTempAnalysis. Setelah semua komponen di-input-kan maka simulasi bisa dijalankan.

Tahap selanjutnya setelah simulasi yaitu hasil tersebut divisualkan dengan Honeybee_Read Ep Result yang dihubungkan dengan Ladybug_3D Graphic untuk medapatkan gambar simulasi dan di-input ke Ladybug_Adaptive comfort Calculator untuk menghitung kenyamanan adaptif berdasarkan kondisi sebenarnya yang di-input. Keseluruhan alur penelitian yang telah dijelaskan dapat dilihat seperti pada Gambar 5.

Tabel 1. Material Bangunan Perumahan Ketaping Residence Tipe 36

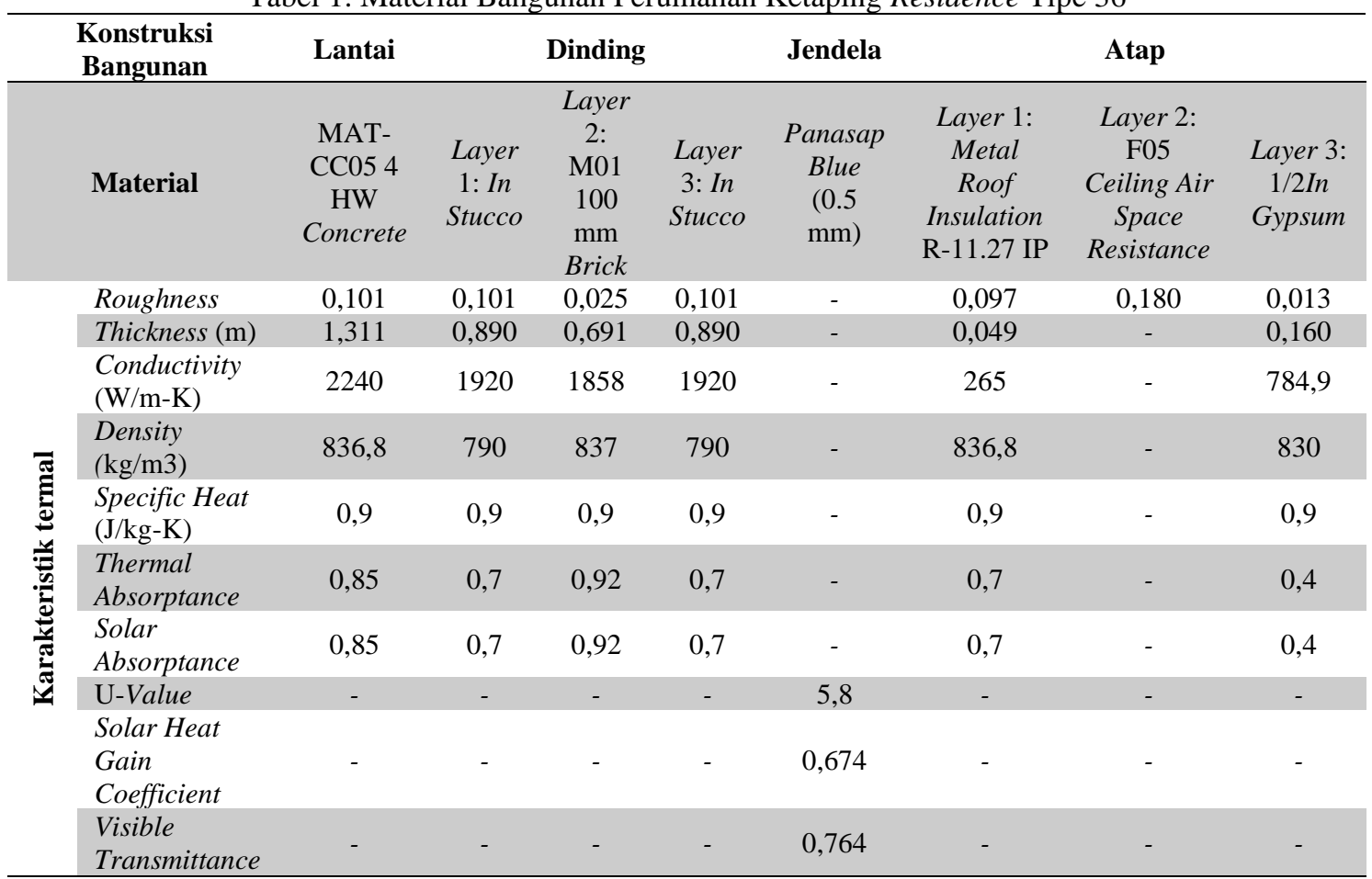

Tabel 2. EnergyPlus Zone Load Rumah Tipe 36 Perumahan Ketaping Residence

\begin{tabular}{ccc}
\hline No & Beban & Angka Satuan \\
\hline 1 & Equipment load pe area $(\mathrm{W} / \mathrm{m} 2)$ & 2 \\
2 & Infiltration rate per area $(\mathrm{m} 3 / \mathrm{s} \mathrm{per} \mathrm{m} 2$ facade $)$ & 0,0003 \\
3 & Number of people per area $(\mathrm{ppl} / \mathrm{m} 2)$ & 0,25 \\
4 & Faction of glazing area operable & 0,40 \\
\hline
\end{tabular}

\section{HASIL DAN PEMBAHASAN}

Dalam pembahasan penelitian ada dua objek rumah contoh yang diambil untuk mewakili populasi objek pada perumahan, yaitu dengan orientasi yang berbeda (Gambar $6 \& 7$ ). Hasil simulasi pada kedua rumah contoh dapat dilihat pada tabel 3, baik untuk ruangan kamar tidur depan, kamar tidur belakang, ruang tamu dan toilet. Untuk kamar tidur depan di Rumah Contoh 1 , persen nyaman per tahun $67,91 \%$, di mana suhu ruangan panas $32,08 \%$. Suhu nyaman standar untuk kamar tidur depan adalah $26,05^{\circ} \mathrm{C}$, dengan suhu nyaman minimum $23,55^{\circ} \mathrm{C}$ dan suhu nyaman maksimum $28,55^{\circ} \mathrm{C}$. Untuk kamar tidur depan di Rumah Contoh 2 , persen nyaman per tahun $95,56 \%$, dengan suhu panas $4,44 \%$. Suhu nyaman standar $26,05^{\circ} \mathrm{C}$, di rentang suhu $23,55-$ $28,55^{\circ} \mathrm{C}$. Kondisi panas pada kamar tidur depan di kedua rumah tersebut terjadi setiap bulannya mulai pukul 12:00 siang hingga malam hari. Di Rumah Contoh 1, suhu nyaman terjadi pada pertengahan Maret dan awal November. Di Rumah Contoh 2, suhu nyaman hanya terjadi di awal November.

Pada hasil simulasi kamar tidur belakang di Rumah Contoh 1, persen nyaman per tahun $60,19 \%$, dengan suhu ruangan panas $39,81 \%$. Ruangan ini memiliki suhu nyaman standar $26,05^{\circ} \mathrm{C}$, dengan suhu nyaman minimum $23,55^{\circ} \mathrm{C}$ dan suhu nyaman maksimum $28,55^{\circ} \mathrm{C}$. Sedangkan di Rumah Contoh 2, persen nyaman per tahun 32,50\%, dengan suhu panas 67,50\%. 
Ruang kamar tidur belakang di Rumah Contoh 2, suhu nyaman ruangan $26,05^{\circ} \mathrm{C}$, dengan rentang

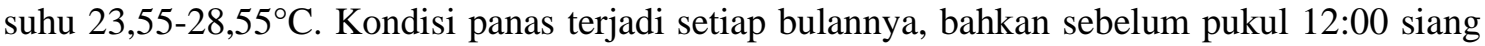
hingga pagi hari. Kondisi nyaman di ruang kamar tidur belakang di Rumah Contoh 1 hampir sama dengan ruang kamar tidur depan, yaitu di pertengahan Maret dan awal November. Dan terjadi suhu panas menjelang akhir November sepanjang hari. Untuk kamar tidur belakang di Rumah Contoh 2, suhu panas sepanjang hari terjadi di akhir Agustus dan November. Dan hampir sepanjang bulan, suhu panas terjadi mulai 12:00 siang hingga pagi hari hari pukul 06:00 pagi, kecuali di April hingga Juli.

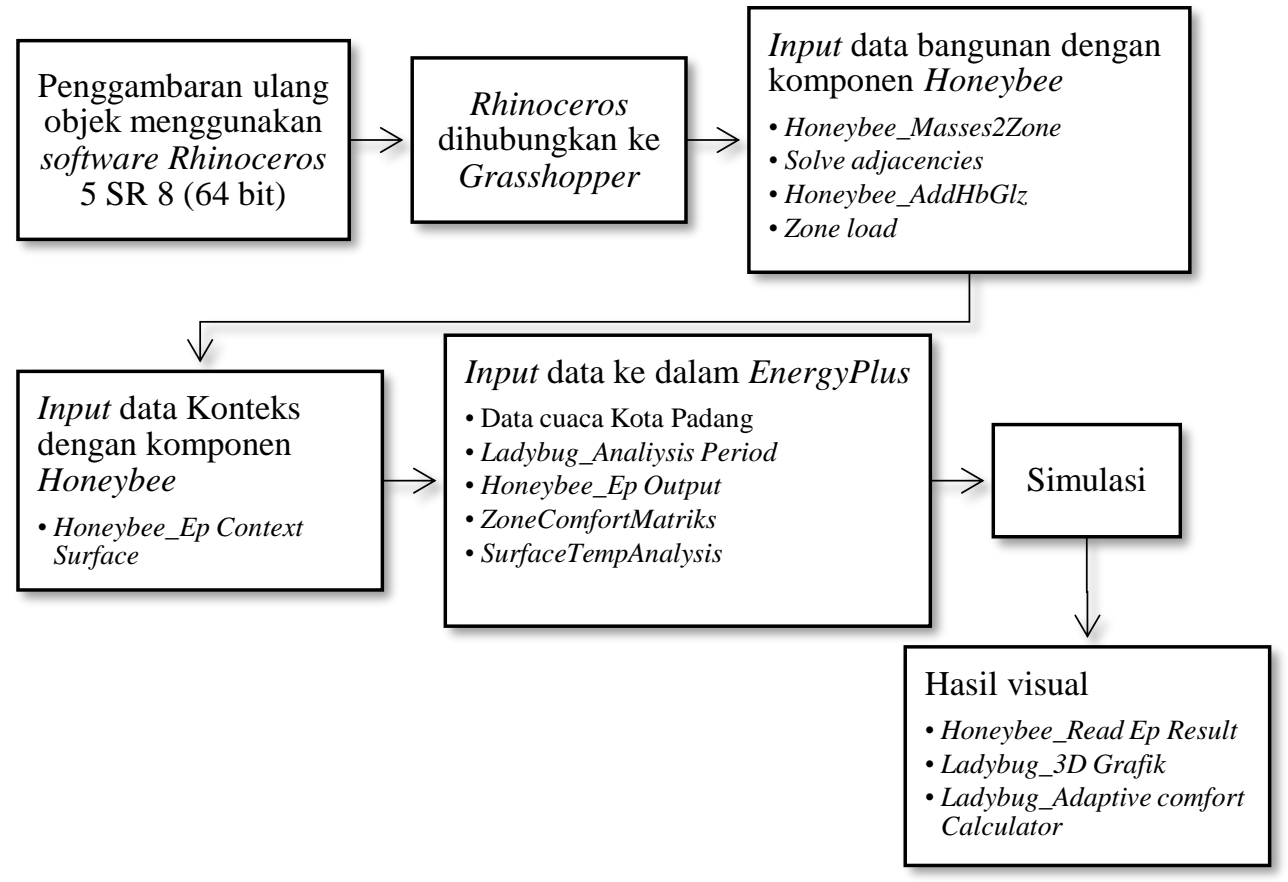

Gambar 5. Alur metode penelitian

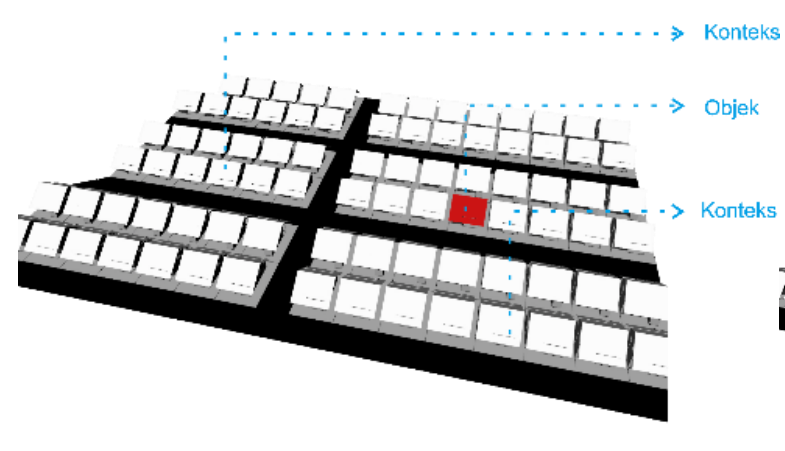

(a)

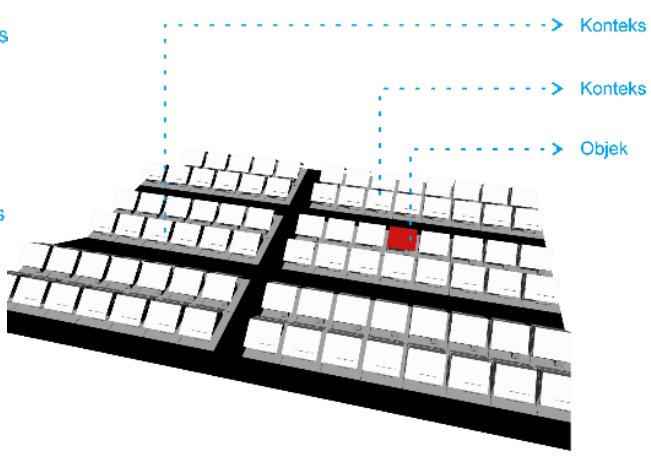

(b)

Gambar 6. Letak rumah contoh (a) Rumah Contoh 1 dan (b) Rumah Contoh 2 


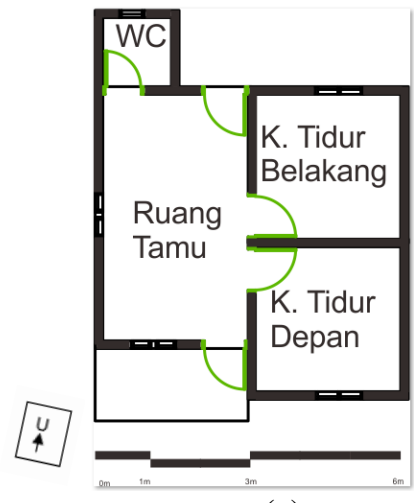

(a)

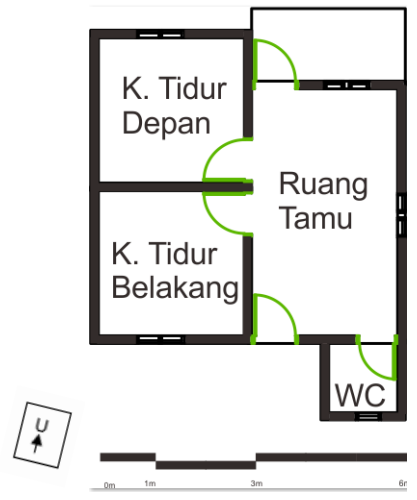

(b)

Gambar 7. Ruang dan orientasi (a) Rumah Contoh 1 dan (b) Rumah Contoh 2

Tabel 3. Hasil Simulasi Pada Ruangan di Setiap Rumah Contoh

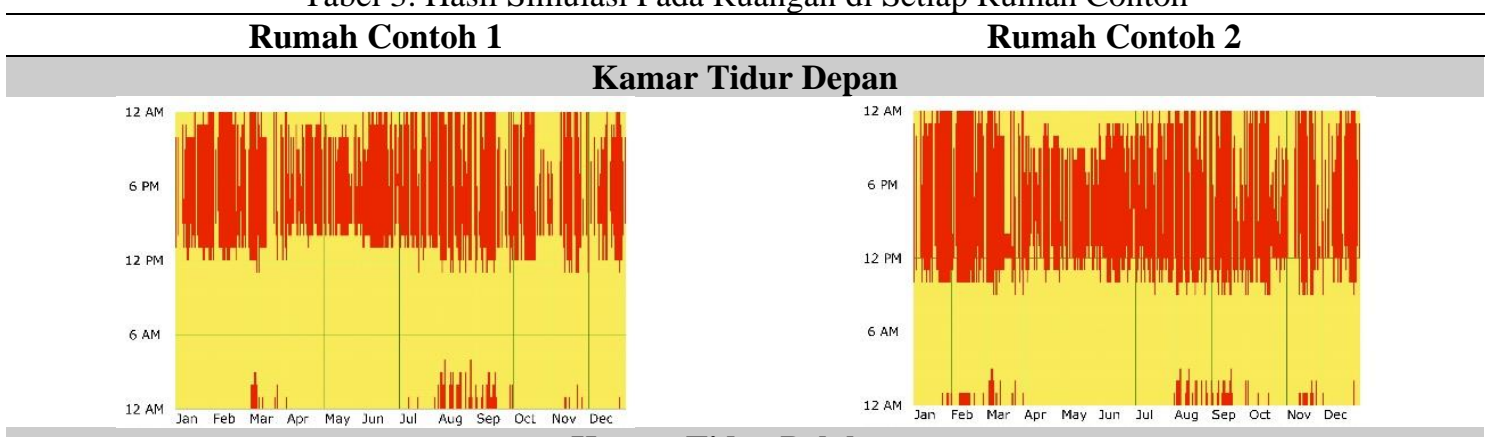

Kamar Tidur Belakang
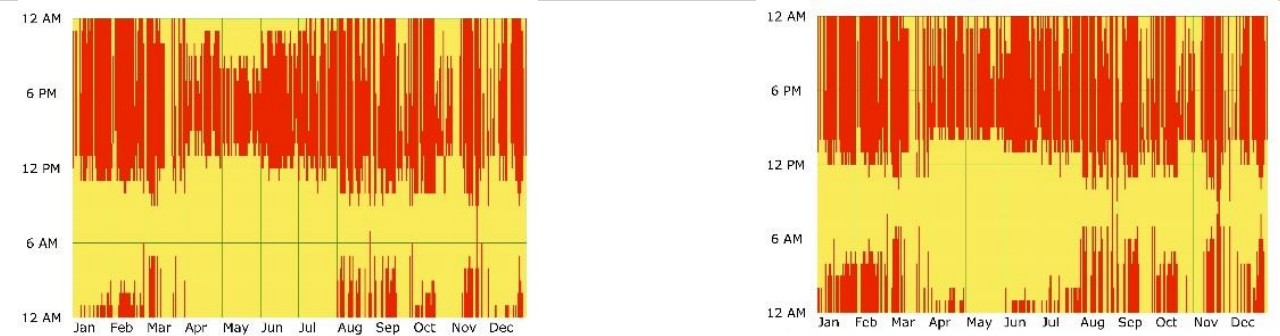

Ruang Tamu
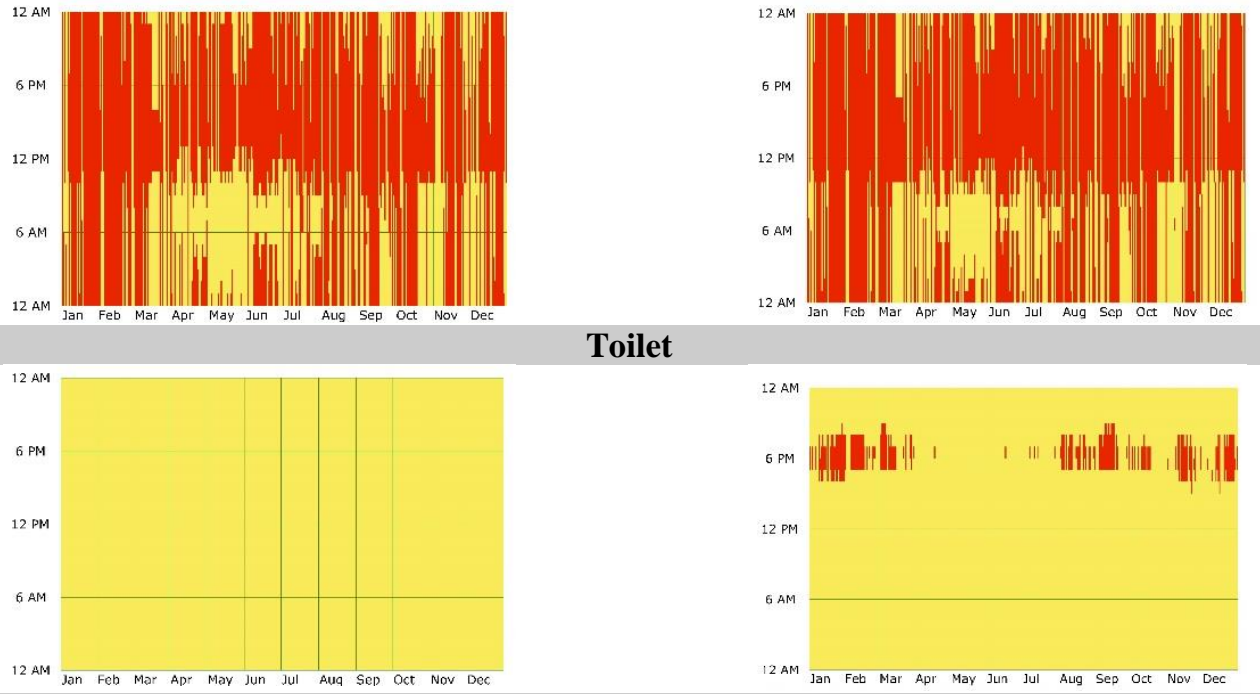

Toilet

12 AM

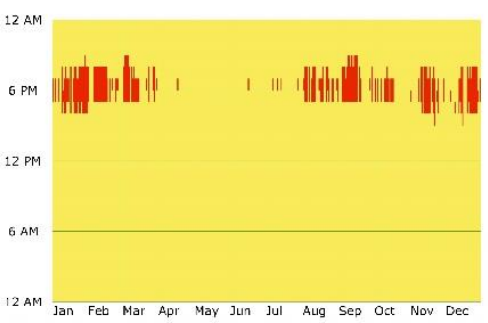

Merah: kondisi panas; Kuning: kondisi nyaman, Biru: kondisi dingin

Hasil simulasi pada ruang tamu baik di Rumah Contoh 1, menunjukan persen nyaman per tahun adalah $35,98 \%$ dengan suhu ruangan panas $64,02 \%$. Suhu nyaman standar ruang tamu di Rumah Contoh 1 adalah $26,05^{\circ} \mathrm{C}$, dengan rentang suhu $23,55^{\circ} \mathrm{C}-28,55^{\circ} \mathrm{C}$. Untuk ruang tamu di 
Rumah Contoh 2, persen nyaman per tahun adalah 56,87\% dengan suhu ruangan panas 43,13\%. Suhu nyaman ruang pada $26,05^{\circ} \mathrm{C}$, dengan rentang suhu $23,55^{\circ} \mathrm{C}-28,55^{\circ} \mathrm{C}$. Di ruang tamu Rumah Contoh 1 suhu panas terjadi sepanjang tahun, di April hingga Juni suhu nyaman terjadi di pukul 06:00-10:00 pagi. Untuk ruang tamu di Rumah Contoh 2, suhu nyaman pagi hanya terjadi di Mei.

Untuk hasil simulasi pada toilet di kedua rumah contoh tersebut, menunjukan kondisi nyaman setiap bulannya. Persen nyaman per tahun di Rumah Contoh 1 adalah 100\%, dengan suhu nyaman standar $26,05^{\circ} \mathrm{C}$, suhu minimum $23,55^{\circ} \mathrm{C}$ dan suhu maksimum $28,55^{\circ} \mathrm{C}$. Di Rumah Contoh 2, persen nyaman per tahun adalah $59,02 \%$, suhu ruangan panas $49,98 \%$, dengan suhu nyaman standar $26,05^{\circ} \mathrm{C}$, dengan suhu minimum $23,55^{\circ} \mathrm{C}$ dan suhu maksimum $28,55^{\circ} \mathrm{C}$. Kondisi suhu nyaman di toilet di Rumah Contoh 1 terjadi sepanjang tahun, dan di Rumah Contoh 2, terjadi suhu panas di Januari-Maret dan Agustus-Desember, di pukul menjelang dan setelah 06:00 sore. Untuk perbandingan waktu nyaman rata-rata pertahun di setiap ruangan pada kedua rumah contoh disajikan pada gambar 8 .

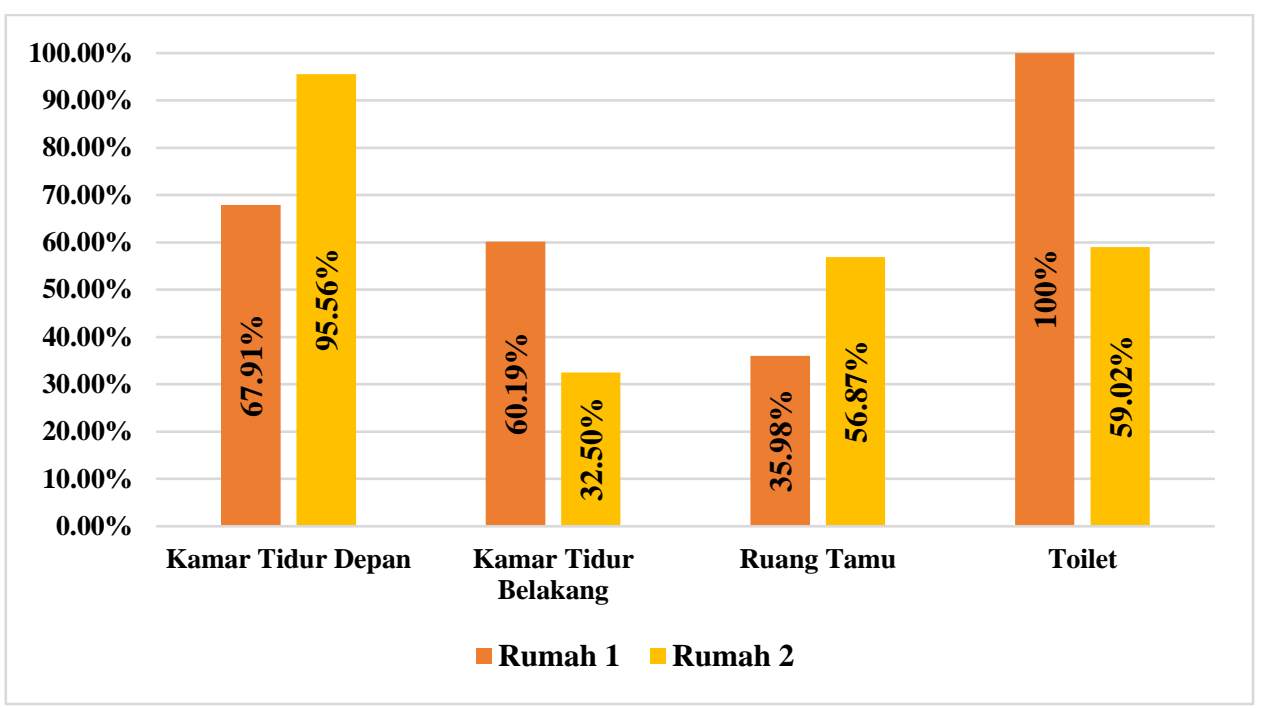

Gambar 8. Persentase perbandingan waktu nyaman setiap ruang per tahun pada rumah Contoh $1 \& 2$

\section{KESIMPULAN DAN SARAN}

Berdasarkan hasil simulasi rumah contoh yang merupakan rumah contoh paling tidak nyaman terjadi pada rumah contoh 2 (dua) yang terletak pada bagian Timur Laut site. Pada rumah contoh ini kamar tidur belakang menjadi zona dengan tingkat persentase nyaman pertahun paling rendah yaitu $32,50 \%$. Kondisi paling nyaman yang terjadi berdasarkan simulasi terdapat pada toilet di Rumah Contoh 1 mencapai 100\% per tahun, dan ruang kamar tidur depan pada Rumah Contoh 2 mencapai $95,56 \%$ per tahun.

Bagian nyaman rata-rata terjadi pada zona yang terletak di bagian sebelah Utara dan Timur Laut bangunan, sedangkan bagian dengan persentase tidak nyaman terendah terjadi pada ruang yang terletak di sisi Barat Daya bangunan. Toilet di Rumah Contoh 1 merupakan zona ternyaman dengan persentase $100 \%$ nyaman pertahun. Hal ini dipengaruhi dengan arah angin yang dominan dan kurangnya radiasi matahari dari arah Utara dan Selatan.

Keadaan nyaman terjadi pada pagi dini hari menjelang siang hari. Bulan Maret-Juli merupakan bulan lebih banyak kenyamanan dibandingkan dengan bulan lainnya. Rata-rata Agustus-September menjadi bulan dengan suhu tidak nyaman, dan panas dirasakan merata setiap waktunya.

Besar dinding bangunan yang terekspos sinar matahari mempengaruhi kenyamanan termal bangunan. Material dan Window to Wall Ratio (WWR) berpengaruh terhadap daya serap panas pada bangunan yang mempengaruhi kondisi termal bangunan. Pada rumah contoh keadaan panas terjadi lebih banyak pada daerah yang berada di sebelah Barat dan Timur bangunan. Hal ini terjadi karena tidak terdapatnya konteks baik berupa bangunan sekitar maupun tumbuhan untuk menghalangi paparan sinar matahari langsung mengenai bangunan. 
Konteks dan penghalang bangunan memiliki pengaruh dalam mengurangi tingkat serap panas dan kontaminasi radiasi matahari pada bangunan. Orientasi memberikan pengaruh pada kenyamanan termal bangunan yang mana bagian Barat merupakan oerintasi dengan kondisi nyaman terendah atau kondisi paling panas. Hal ini disebabkan karena Kota Padang terletak di wilayah khatulistiwa, radiasi surya dari arah Barat (yaitu pada sore hari) lebih dominan/besar nilainya dibandingkan dari arah yang lain.

\section{DAFTAR PUSTAKA}

[1] S. R. Wafi, M. R. Ismail, and E. M. Ahmed, "A Case Study of the Climate Factor on Thermal Comfort for Hostel Occupants in Universiti Sains Malaysia (USM), Penang, Malaysia," J. Sustain. Dev., vol. 4, no. 5, pp. 50-61, 2011, doi: 10.5539/jsd.v4n5p50.

[2] ASHRAE, "Thermal Environmental Conditions for Human Occupancy," Am. Soc. Heating, Refrig. Air- Cond. Eng., 2010.

[3] J. Rilatupa, "ASPEK KENYAMANAN TERMAL PADA PENGKONDISIAN RUANG DALAM," 2008.

[4] A. SNI - 03 - 6572, "Tata Cara Perancangan Sistem Ventilasi dan Pengkondisian Udara pada Bangunan Gedung," pp. 1-55, 2001.

[5] R. J. De Dear and G. S. Brager, "Thermal comfort in naturally ventilated buildings: Revisions to ASHRAE Standard 55," Energy Build., vol. 34, no. 6, pp. 549-561, 2002, doi: 10.1016/S03787788(02)00005-1.

[6] E. Rachmad, "Jurnal Ilmiah,” Anim. Genet., vol. 39, no. 5, pp. 561-563, 2008.

[7] Atthaillah, E. Saputra, and M. Iqbal, "Adaptive Comfort Pada Grand Studio Program Studi Arsitektur Fakultas Teknik Universitas Malikussaleh," Nature, vol. 4, no. 2, pp. 83-91, 2017, doi: https://doi.org/10.24252/nature.v4i2a1.

[8] R. de Dear, "Recent Echancements to the Adaptive Comfort Standard in ASHRAE 55-2010," 45th Annu. Conf. Archit. Sci. Assoc. ANZAScA 2011, Univ. Sydney, 2011, doi: 10.1097/PRA.0000000000000252.

[9] Y. H. Prasetyo, "Analisis Kinerja Termal dan Aerodinamis pada Rumah Tradisional Batak Toba Menggunakan Simulasi Digital dan Pengukuran Lapangan,” vol. 2, no. 2, 2016.

[10] M. S. Roudsari and M. Pak, "Ladybug: A Parametric Enviromental Plugin For Grasshopper to Help Designers Create an Enviromentally-Conscious Design," 13th Conf. Int. Bui;ding Perform. Simul. Assoc. Chambery, Fr., vol. 25, pp. 11-24, 2010, doi: citeulike-article-id:8354697. 